CZU:821.135.1-92.09

https://doi.org/10.52505/filomod.2021.15.42

\title{
PUBLICISTICA LUI ALEXANDRU ROBOT: RECUPERĂRI NECESARE
}

\author{
ȘTEFAN SUSAI \\ Școala doctorală Științe Umaniste, USM
}

\begin{abstract}
Rezumat. Alexandru Robot a fost unul dintre publiciștii importanți ai perioadei interbelice. A fost un model de stil și limbaj pentru jurnaliștii basarabeni din acea vreme. In articolele sale, descoperim un Chișinău trist, plin de sărăcie și mizerie. Scriitorul îl caracterizează prin imagini simbolice care vestesc o apocalipsă. Natura devine cadrul predilect de conturare a sfâșierilor interioare ale acestui poet nimerit într-un spațiu cultural marginal, într-o lume in care spiritul său creator nu avea cum să se afirme.
\end{abstract}

Cuvinte-cheie: publicistică, stil, limbaj, dezolare, imaginar apocalyptic.

Abstract. Alexandru Robot was one of the greatest publicists of the interwar period. He was a model of style and language for the Bessarabian journalists of that time. In his articles, we discover a sad Chișinău, full of poverty and misery. The writer characterizes it using symbolic images that announce an apocalypse. Nature becomes a favorite framework for shaping the inner state of this poet who finds himself in a marginal cultural space, in a world in which his creative spirit could not assert itself.

Keywords: journalism, style, language, desolation, apocalyptic imaginary.

Alexandru Robot a fost unul dintre publiciștii importanți ai perioadei interbelice. Născut la 15 ianuarie 1916, la București, Alexandru Robot și-a întrerupt studiile liceale pentru a lucra publicist. Înainte de venirea la Rampa, unde s-a consacrat a mai publicat în revistele Discobolul, Bobi, Vremea, Floare de foc, Viața literară. La Rampa el a îngrijit rubricile $P e$ marginea cărților, Un sfert de oră cu scriitorii, Actualitatea și Capitala, Carnetul Rampei. În perioada 1932 - 1934, el semnează uneori și câte două materiale pe zi, devenind astfel unul dintre principalii colaboratori ai Rampei, publicație care se intitula Ziar zilnic de teatru, literatură, artăa muzică, sport și cinema.

Rubrica Un sfert de oră cu scriitorii, susținută de Robot, este o imagine a vieții literare din acea perioadă. El intervievează scriitori precum Panait Istrati, N. D. Cocea, Mircea Eliade, Tudor Arghezi, Ionel Teodoreanu, D. N. Davidescu, F. Aderca, Liviu Rebreanu, Gala Galaction. Interviurile lui Robot introduc cititorul în spațiul intim al unor scriitori consacrați. Prin faptul că publicistul face o descriere a locului unde stă respondentul său, 
a anturajului în care acesta activează și oferă alte informații revelatoare, care țin de un ascuțit simț de observație, interviurile devin eseuri relevante pentru istoria noastră literară. Pe N. D. Cocea îl vizitează la locuința lui din Sighișoara și descrie atât de sugestiv anturajul și preocupările scriitorului, încât interviul capătă rezonanța artistică a nuvelei.

Din interviurile lui Alexandru Robot apar amănunte inedite pentru cititor, spre exemplu, că Ionel Teodoreanu și-a scris romanul Golia în casa lui Ibrăileanu care „era tăcută ca o mănăstire”; Arghezi lucra „fără proiect și fără deviz” și viața lui se derula printre „flori de stil și printre legume”. Interviurile sunt pline de comentarii subiacente, înzestrate cu umor, care întretaie ingenios replica interlocutorului. Intervievându-l pe actorul G. Ciprian, îl contrazice între paranteze cu vădită plăcere: „Cum prepar un rol? N-am propriu-zis vreun sistem după care procedez. Experiența și repetiția sunt cele două elemente de care mă servesc [N.R. Şi totuși domnul Ciprian lipsea de la repetiție!]”. Publicistul profilează în interviurile sale ipostaza umană, imediată, telurică a scriitorului, în anturajul lui cotidian, în contextul lui de creație.

Vizita la Panait Istrati este o recuperare autentică a imaginii din ultimii ani a scriitorului bolnav, aflat pe un pat de spital. În dialogul lor transpar crâmpeie de umanitate vie, netrucată literar:

L-am revăzut mai obosit și mai palid. Culcat, cu ochii ascunși în adâncimea orbitelor, imi povestea:

- Mi-a furat pe drum un aparat fotografic. Ştii că asta a fost profesia mea, dar acum lucrez ca amator, cu un aparat perfecționat.

- Şi ați reclamat poliției?

Panait se indignează:

- Să reclam poliției? Eu, tocmai eu? Păi, intre poliție și hoț, eu mă solidarizez cu hoțul. Şi Istrati era sincer. Umanitatea lui era generoasă. Simpatiza cu cei de la periferia societății și iși amintea că într-o epocă fusese dacă nu pungaș, complice de pungaș, constrâns să recurgă la această modalitate de-a astâmpăra foamea. (Amintiri despre Panait Istrati)

Rubrica Actualitatea și Capitala, ținută de Alexandru Robot în Rampa ne oferă o imagine a cotidianului din Bucureștiul acelor ani. Gara este pentru Robot o lume aparte, în care găsește permanent aspecte interesante ale vieții. Carnetul Rampei include reflecții ale lui Robot pe teme de interes social și cultural. „,Am auzit că la Iași cimitirul local se intitulează Eternitatea. Am de gând să mor acolo. E singura modalitate de a intra în eternitate" (Cimitirele). Publicistul Robot emite opinii despre fenomene literare, genuri și specii artistice, și chiar dacă acestea nu au valoare de reper teoretic sau critic, sunt interesante prin felul în care el manevrează cu idei însuşite de prin cărți, cu intuiții de scriitor și cu observații din experiența sa de reporter. Într-un articol din Rampa el reflectează la relația 
dintre reportaj și roman, acordând prioritate reportajului în ceea ce privește investigarea realității. Pe marginea cărților este rubrica în care publicistul Robot consemnează noile apariții editoriale.

Ajuns, în 1935, la Chișinău, Robot devine reporter la Gazeta Basarabiei și își orientează atenția asupra locurilor basarabene. În articolele sale, descoperim un Chișinău anost, plin de sărăcie și mizerie. Scriitorul îl caracterizează prin imagini simbolice dezastruoase, pe care i le sugerează un element, un detaliu relevant, cum ar fi, spre exemplu, imaginea ciorilor, niște „pajuri ale mizeriei”: „Pentru un călător care a văzut orașele din Ardeal pline de porumbei albi, ciorile Chișinăului arată, mai mult decât orice, diferența dintre două lumi”. Descrierea e cu totul dezolantă, răvășitoare:

Ciorile desuete și dezagreabile, rupte parcă dintr-un steag de doliu, embleme și simboluri ale nenorocirii, care nu se desparte de destinul Basarabiei, sunt caracteristice pentru un oraș cu două linii de tramvai, dintre care una merge la spital și alta la cimitir. (Pajurile mizeriei chișinăuiene)

Din aceste pagini ale lui Robot despre Chișinău străbate tristețea, dezamăgirea. Imaginarul lui capătă reflexele tanaticului, e străfulgerat de convulsia naufragiatului care-și presimte visceral moartea și pentru care realitatea capătă proiecții simbolizante. Ploaia îi sugerează o atmosferă a sfârșitului de lume:

Străzile sunt inundate și, ca să traversezi, trebuie să plătești un leu unui băiat, care te trece de cealaltă parte a drumului cu o scândură. Tot astfel e și în infern, când luntrașul Caron cere un ban de argint ca să te treacă Styxul. (Toamna nevoilor)

Până și zarzavaturile, țăranii le pun la murat în butoaie „ca niște urne funerare”. La fel și târgurile basarabene îi dezvăluie imagini „de arhitectură strâmbă, de ziduri ruinate, de uliți rătăcite fără fantezie". Sculeniul interbelic, decrepit și rupt de civilizație, acutizează impresia, care este și o stare, de periferie, pe provincie tristă, ruptă de civilizație:

Alte aspecte din bariera Sculeni? Periferia asta are un singur și neînțeles aspect. Casele mici și cocoșate, drumul îngropat în praf și străbătut de carele cu boi, cârciumile care alcoolizează pe locuitori - iată elementele disparate ale unui aspect unic și general. (Portretul unei periferii)

Pe de altă parte, oroarea pentru toposul Chișinăului este contrabalansată de milă și empatie pentru oamenii locului:

Prin restaurante, felia de pepene are prețul cu care se vând $\hat{i n}$ provincia noastră cinci pepeni și în tot comerțl fructele n-au aceeași decadență, care ți se revelează în scurta oprire a unui tren prin gările basarabene. $N u$ cunosc argumentele economice care refuză debușee 
in Vechiul Regat pentru fructele noastre, nu văd motivul pentru care în Ardealul nostru cu vinuri mediocre vinul pur basarabean nu-și găsește locul indicat pe piață. (Destinul fructelor basarabene)

Este evident că scriitorul manifestă un interes aparte pentru aspectele dramatice ale realității. Paginile în care vorbește despre Comratul ca o, vale a plângerii”, despre „ghetoul musulman Anadolchioi”, despre cazinourile ca spații ale ruinei omenescului, despre sărăcia și mizeria orașelor prin care trece etc. sunt și cele mai emoționante, scrise cu trăire empatică, trecute printrun spirit critic rafinat. Talentul de peisagist se manifestă plenar în imagini şocante, revelațiile cotidianului îi provoacă publicistului asocieri dintre cele mai neobișnuite:

Casele și-au deschis ferestrele, iar în balcoane atârnă covoare aşa cum câinilor le atârnă limba; garderoba doarme ca niște spânzurători numerotate. (Paștele la Rusciuc)

Comparațiile lui țin de registrul avangardist, denunțând în reporter poetul nonconformist din Apocalips terestru. În piața chișinăuiană, bulionul ardeilor și a cartofilor „e roșu ca hemoragia”, iar „cartofii par bulgări de pământ. Îți vine să-i iei și să-i arunci peste un sicriu imaginar. Ardeii, întinși pe o ață ca un colier, sunt degete roșii, care putrezesc atârnați în cui”. Priveliștea pieței de carne ține de un imaginar terifiant:

...abdomene spintecate ca într-un hara-kiri, creieri scoși din cutia lor, inimi smulse și fudulii decapitate. Măcelarii cu infățișare de călăi împlântă cuțitele în carnea animalelor jertfite și cu gesturi abile de chirurgi taie un ficat sau un mușchi. (Aspecte din piața nouă)

Publicistica lui Robot ne dezvăluie aspecte mai puțin cunoscute ale Basarabiei interbelice, iar genului publicistic, așa cum era practicat atunci în revistele basarabene, îi ofereau o lecție de grație și rafinament stilistic. „Cel puțin generația mea, scrie Eugen Lungu, a învățat câte ceva anume de la acest acrobat al stilului."

Înzestrat cu har și cu o neobișnuită putere de muncă, Alexandru Robot a scris în câțiva ani câți alți scriitori într-o viață. Dacă nu dispărea la o vârstă prematură, am fi vorbit, poate, de un scriitor de mare prestigiu. Chiar şi așa, publicistica lui Robot este o pagină importantă a literaturii române din Basarabia, recuperarea căreia se impune.

După instaurarea comunismului în România, publicistica lui Alexandru Robot a fost trecută sub tăcere o lunga perioadă de timp. El murise în anul 1941, retrăgându-se din Basarabia cu trupele sovietice. La Chișinău avea să apară, la editura Cartea Moldovenească, în anul 1968, o ediție de Scrieri Alese, sub îngrijirea lui Simion Ciubotaru. A fost prima încercare de recuperare a publicistului, romancierului și poetului Alexandru Robot la mai bine de un 
sfert de veac de la dispariția lui. „Despre Alexandru Robot s-a scris în trecut și se vorbește în prezent numai ca poet, proza și activitatea publicistică a scriitorului rămânând oarecum în urmă. Latura aceasta a creației lui prezintă un mare interes. Și nu numai din punctul de vedere al cantitătii materialelor publicate în presă." (Simion Ciubotaru, p. 17, Scrieri Alese, Robot, Cartea Moldovenească, 1968).

Volumul menționat readuce în atenția cititorilor o parte din publicistica lui Robot, mai ales cea apărută la Chișinău. Selecția materialelor a fost făcută astfel încât să servească ideologiei acelor ani. În unele cazuri, s-a creat oarecum impresia că Robot a fost mai mult un publicist care slujea comunismul. Robot trăia la limita sărăciei, deplângea inechitățile sociale într-o epocă în care antisemitismul sufoca o bună parte a Europei. Ca și mulți alți scriitori, Robot a văzut în ideologia comunistă o alternativă. Este drept, a scris versuri și publicistică ce au servit Uniunii Sovietice după anexarea Basarabiei. Însă totalitatea operei publicistice a lui Robot nu trebuie analizată prin prisma ideologiei, așa cum reiese din volumul menționat.

În anul 1985 apare, la Editura Minerva din București, o ediție a Scrierilor lui Alexandru Robot. Publicistica lui Robot la Rampa este adusă în atenția cititorilor alături de poezie. Alcătuitorii ediției menționează că din anul 1940 Robot, stabilit la Chișinău, scria și colabora la Moldova socialistă, Comsomolistul Moldovei, Octombrie, Scânteia leninistă. Nu este reluat însă vreunul din articolele publicate la gazetele menționate pe care le regăsim în ediția tipărită la Chișinău în anul 1968.

Recuperarea publicisticii lui Robot are loc cu adevărat abia în 2018 și 2019. La editura Științta din Chișinău apar două volume: „Eseu. Publicistică. Cronici. Interviuri” și „Poezie. Proză. Publicistică. Eseu. Ediția îngrijită de Nina Corcinschi îl redă practic literaturii române pe Alexandru Robot. „Prin tot ce a scris, Alexandru Robot a demonstrat o mare forță artistică, un excelent potențial literar, a confirmat printr-o asumare totală a scrisului, cu acoperirea de cele mai multe ori reușită a tuturor genurilor literare: poezie, proză, eseu, publicistică și chiar dramaturgie." Publicistica lui Alexandru Robot rămâne o pagină de referință a literaturii române, iar recuperarea ei a fost extrem de necesară. Robot ca poet, romancier și publicist are locul său în Istoria Literaturii Române.

\section{Referințe bibliografice:}

1. CĂLINESCU, George. Istoria Literaturii Române, Fundaţia Regală pentru Literatură și Artă, București, 1941, p. 881.

2. CERNAT, Paul, Avangarda românească şi complexul periferiei, Cartea Românească, București, 2007.

3. CIOCANU, Ion. în revista Cultura din 5 aprilie 1969.

4. CIUBOTARU, Simion. (ed.) Scrieri Alese. Editura Cartea Moldovenească, Chișinău, 1968. 
5. POPESCU, Aristide (ed.). Alexandru Robot. Scrieri. Editura Minerva , 1985, București.

6. CORCINSCHI Nina (ed.), Alexandru Robot. Scrieri. Poezie, Proză. Publicistică. Eseu. Editura Știința, Chișinău, 2018.

7. CORCINSCHI, Nina (ed.). Alexandru Robot. Scrieri. Eseu. Publicistică. Cronici. Interviuri. Editura Știința, Chișinău, 2019.

8. LUNGU, Eugen, Raftul cu himere, Chişinău, Ed. Ştiinţa, p. 151.

Notă: Articolul a fost realizat în cadrul proiectului de cercetare 20.80009.1606.03 Contexte socioculturale autohtone şi interconexiuni europene în creaţia populară şi literatura cultă din Basarabia (sec. XIX până în prezent), Institutul de Filologie Română „B. P.-Hasdeu” al MEC. 